\title{
Commitment to the Sustainability of Students within a Responsible Management Education
}

\author{
Małgorzata Okręglicka ${ }^{1}$
}

\begin{abstract}
Higher education has always responded to the social needs. Universities can play a critical role in the process of social change that relies on educating new generations of leaders and citizens. Higher education shapes the attitudes of many future managers, decision makers, planners, and educators. It has the potential to prepare students and increase information and knowledge in order to move towards a sustainable future. This is why higher education should be involved in implementing the programs of education for sustainable development. The main aim of the paper is the diagnosis of the current student commitment to the sustainability developed by higher education system and its influence on intention to apply the principles of sustainable development in the future. Tools of research included the literature review and questionnaire. The hypotheses are empirically tested with survey data obtained from Polish students of management. The descriptive statistics and correlation analysis will be used in empirical data analysis to achieve the paper goal. By this diagnosis the recommendations for improving responsible management education could be formulated. As a result, students could obtain a high degree of involvement, increasing awareness on their role in society and need for applying the principles of sustainable development, especially taking care of the environment and acting as a responsible member of society.
\end{abstract}

Keywords: sustainability, responsible management education, attitudes, education system, management

\section{Introduction}

The sustainability challenges become more and more growing concerns in contemporary society. The socio-economic, cultural and ecological dimensions must be taken into account in order to find and follow a path of sustainable development that ensures justice across the generations (Adomßent, 2014).

The Brundtland Report traditionally defines sustainable development as "development that meets the needs of the present without compromising the ability of future generations to meet their own needs" (WCED, 1987, p. 43). Sustainable development need to integrate social, economic, and ecological aspirations, goals, values, and related practices. In the common sense, the concept of sustainability tended to be identified with environmental issues emphasizing the need of a balance between economic growth and ecological carrying capacity. Present understanding of the term is much wider, and has come to include sociocultural aspects as well (Wu et al., 2010).

Problems with sustainability appear with the strongest intensity in human professional life. The tendency to profit generation is often in opposition to the issues of sustainable development. Meanwhile, sustainability in business management requires a organization's environmental and social responsibilities to be given the same importance as its 
economic concerns (Neubaum et al., 2009; Haviernikova et al., 2016).

The need of sustainable solutions in nature and human life should be reflected in the programs of education for sustainable development. For the present and future communities, there is a priority to create or rethink and revise educational programs towards sustainability, which should occur from preschool to university to integrate the principles, knowledge, skills, and values associated with sustainability (Faham et al., 2017).

In many studies the emphasis is on the necessity of integrating the education programs for sustainable development into the higher education (Verhulst \& Lambrechts, 2015; Figueiro \& Raufflet, 2015) to create the knowledge and skills for dealing with global challenges such as food security, climate change, water and non-renewable energy management, health, and social inequality. As education for sustainable development affects all components of higher education (Faham et al., 2017) it should be implemented and realized in systematic, a thoughtful way. The goal of higher education for sustainable development is to enable individuals to reflect, through multicultural, global and future oriented perspectives, on their responsibility for the complex effects of decision-making and behavior.

Higher education has always responded to the society expectation. Thus, the higher education institutions worldwide started to change their educational mission and procedures for integrating sustainability into the educational system (Stephens \& Graham, 2010). Universities can play a crucial role in the process of social change which relies on educating new generations of leaders and citizens (Faham et al., 2017; Lemańska-Majdzik, 2015). Rieckmann (2012) underlined that the university should integrate education for sustainable development into its curricula in order to enable future professionals to cope with issues of sustainable development in their professional work.

Setó-Pamies and Papaoikonomou (2016) stated, that universities are multilevel learning environments, so there is a need to look beyond formal curricular content and pay more attention to implicit dimensions of the learning process. According to Sterling et al. (2013, p. 7), sustainability can be built into two distinct levels within higher education designed learning (through educational programs) and institutional learning undertaken by those senior managers and policy-makers who are in the position to implement system changes. Integrating sustainability into all education levels may be a reflection of the structuralism approach (Dobson 2007), which assumes that commitment and behaviors can change only if appropriate structures change and policies are implemented. Each university with sustainable approach should become a learning institution that creates teaching and learning settings characterized by aspects of inter- and transdisciplinarity, participation, problem orientation, and linking of formal and informal learning to support the development of key competencies for dealing with the challenges of sustainable development (Lambrechts et al., 2013)

\section{Literature Review}

Taking into account the changes in the global growth model, failures in the previous management theory of economic growth and the development of idea of 
corporate social responsibility in corporations have led to a new management paradigm (Anninos \& Chytiris, 2012). Nowadays, sustainable management gets significant attention and has become a new model of thinking for organizations which take into consideration on their impact in a wider context and the right of not only present but also future generations to meet their own needs by utilizing natural, social and human resources. This management paradigm links the principles of sustainable development and corporate social responsibility and synthesizes them with the management concepts. Thus, sustainable management can be interpreted as a management practice utilizing sustainability concepts by managing a business in responsible way that is providing value creation for business, society and the environment simultaneously (Kolb, 2016). For implementing sustainable management in business life, there is a need of creation the commitment to sustainability of every human being, but especially leaders actively shaping social and economic environment.

Higher education fosters many future managers, planners, decision makers, and educators (Fien, 2002). Universities have the potential to prepare students and increase information and knowledge in order to move them towards a sustainable future.

Responsible management education within higher education focuses on all those activities which hone the conceptual skills and develop the managerial aptitude of students (Rawal, 2013). The graduates as future leaders and inheritors of technology can be a crucial part of the solution of sustainability challenges (Woodruff, 2006). Within higher education system, the commitment and sustainability competencies should be provided creating a framework for today's students, who are future problem solvers (Wiek et al., 2011; Okręglicka et al., 2017). Rieckmann (2012) pointed, that sustainability competencies can be described as combination of knowledge, skills, and attitudes that enable to solve real-world sustainability challenges. Business and management graduates need a responsible education in form which helps them to realize their potential to make a positive contribution to the three pillars of sustainable development: social wellbeing, economic stability, and ecological integrity (Baumann-Pauly et al., 2013). The range of competencies and attributes required by future business leaders to effectively contribute to society's transformation towards sustainability is wide. Particular attention is now being paid to how novel solutions in teaching curricula and pedagogies can engender 'future-facing' graduates with attributes to meet future challenges. Arguably, management graduates require critical and creative competencies, which promote resilience and innovation in the face of the manifold and global threats to human wellbeing and environmental conditions (Warwick et al., 2017).

Analyzing the characteristics of education for sustainable development, Pace (2010) indicated the below elements, which should be taking into account when trying to make any changes in existing standards:

- basing on the principles and values of sustainable development including its the evolving nature and deals with the well being of all three domains of sustainability: environment, society and economy, ;

- promoting life-long learning;

- engaging formal, non-formal and informal education;

- interdisciplinary in scope;

- taking into account context, global issues and local priorities by content creation; 
- basing on local needs, perceptions and conditions, but with awareness of their international effects and consequences;

- locally relevant and culturally appropriate;

- building civil attitudes towards community-based decision-making, social tolerance, environmental management, adaptable workforce and quality of life;

- using a variety of pedagogical techniques that promote participatory learning and higher-order thinking skills.

Sustainability can be integrated through a narrower or discipline-specific focus (within the management discipline), or can refer to a broader or more cross disciplinary focus (across the business school). Many authors advocated for integrating sustainability within and across disciplines (Rusinko \& Sama, 2009; Steketee, 2009) expressing the need for a broader based approach to integrating sustainability in management education- that is, beyond the management discipline and into the broader business curriculum.

Nowadays, there is a growing academic discussion about areas of management education which should be transformed in order to educate the future managers and leaders to produce sustainable business solutions. Cortese (2003) pointed four separate dimensions of higher education institutions: education, research, university operations and external community, where the modifications are needed. Most efforts in the field of sustainability management education focus on education (curricula) and campus operation, but in limited scope, it means mainly in relation to the environment (Waas et al., 2010). However, the amount of areas to transformation is much wider. Kolb et al. (2017), based on literature, indicated the major elements to be transformed:

- curricula reorientation (rethinking and reforming education);

- development of graduates with appropriate skills and competencies;

- supply corporate social responsibility education for practitioners;

- development of the specialist with skills and knowledge within corporate social responsibility education for industries;

- increase in public awareness of sustainable development;

- conducting research to advance knowledge on corporate social responsibility;

- workforce training;

- implementing sustainability within one's own university;

The idea of educating the management students for sustainable development was formalized in form of the Principles of Responsible Management Education (PRME), which has been coordinated by the United Nations since 2007 (Forray \& Leigh, 2012). PRME provides six guiding principles to encourage business schools and universities to recognize their role as drivers of sustainable change and to adapt their curriculum, pedagogy and institutional strategies (Six Principles, 2018):

1. Purpose: developing the capabilities of students to be future generators of sustainable value for business and society at large and to work for an inclusive and sustainable global economy.

2. Values: incorporating into academic activities, curricula, and organizational practices the values of global social responsibility as portrayed in international initiatives such as the United Nations Global Compact.

3. Method: creating educational frameworks, materials, processes and environments that enable effective learning experiences for responsible leadership. 
4. Research: engaging in conceptual and empirical research that advances our understanding about the role, dynamics, and impact of corporations in the creation of sustainable social, environmental and economic value.

5. Partnership: interacting with managers of business corporations to extend our knowledge of their challenges in meeting social and environmental responsibilities and to explore jointly effective approaches to meeting these challenges.

6. Dialogue: facilitating and support dialog and debate among educators, students, business, government, consumers, media, civil society organizations and other interested groups and stakeholders on critical issues related to global social responsibility and sustainability.

The Six Principles of PRME provide a framework for education institutions to embed sustainable development and ethics into the curriculum, within and across disciplines.

With specific reference to business and management education, PRME has played a vital role in the growing recognition of the need for future business leaders who are responsible. This requires an awareness of sustainability issues and solutions and, optimally, a strong understanding of the challenges and rewards (financial and otherwise) of running organizations which treat sustainable development as one of priorities (Prandi, Martell, \& Lozano, 2015).

While issues of sustainability and responsible management education figure prominently on the international agenda, most universities appear to have yet to respond in a coherent way to determining the key competencies in this area. Godemann et al. (2011) indicated that there is still a vague articulation of the specific competencies universities intend to foster through responsible management education. If management education curricula are to be redesigned, it seems that more debate and researches are needed about adequate competencies future managers will need in order to deal with complex issues in a more responsible and sustainable way.

Sustainability aspects have been included in higher education curricula but not without difficulties (Holm et al., 2015). Leal Filho (2011) identified four main challenges regarding implementation of sustainability aspects in higher education:

- the need of interpreting sustainability with a wider meaning, and not, for example, solely in ecological terms;

- the need of translating the "added" value of sustainability to different stakeholders;

- the need to raise further financial support and obtain commitment from management and various stakeholders;

- the need for concrete projects that demonstrate the result which can be achieved, the reason for this and the way of realization.

Despite the obstacles, universities should express their engagement in responsible education by commitment to sustainable development. Declared commitments should be expressed in the curriculum content and learning outcomes to have effects on students' perceptions and behavior (Dagiliūté, 2018). In this way today's students can be prepared to implement solutions for sustainable development in their future professional and personal life.

On the basis of given literature following hypothesis can be formulated:

H1: The commitment to the sustainability undertaken during the university education determines the intention to apply the principles of sustainable development in the future life. 


\section{Methodology of the Research}

The researches on management education for sustainable development are common and multilateral; however, it requires the constant completion. Approaches to sustainability-related issues are diverse, and challenges are uniquely different between nations and cultures (Matten \& Moon, 2004). Thus, even limited, local research in this area can contribute to this complex issue.

The main aim of the paper is the diagnosis of the current student commitment to the sustainability developed by higher education system and its influence on intention to apply the principles of sustainable development in the future. The research was organized in logical manner. The first step was the in-depth literature overview, which confirmed the importance of the topic and justified of the additional research in the area. Next, online questionnaire survey was realized. The survey was conducted in the first quarter of 2018 among 300 management students. Sampling was purposeful in scope as the students belong to one higher education unit - Faculty of Management in Czestochowa University of Technology. Selected respondents completed the survey questionnaire in online form.

In total, 300 full questionnaires were collected, which were subjected to further statistical analysis. All questions considered the students opinion about the sustainable issues, for which the 7-point Likert scale was adopted, as the most widely used approach to scaling responses in survey research. After data collection, they were entered into a statistical program Statistica 13.1. For evaluation, the descriptive statistics and Kendall Tau correlations analysis were calculated.

The research should be treated as an initial study, and was carried out to identify areas of further study rather than to generalize the findings.

\section{Results}

The first part of the survey was a diagnosis of the commitment to the sustainability, which students obtained within the education process at the university. The form of questions in this part was adopted from Faham et al. (2017) as a part of these authors' wider research.

The descriptive analysis showed rather positive level of education for sustainable development (Tab. 1). Students declared their commitment in value between 4 and 5 in 7 -point scale, however, the results were varied. The highest mean of answers generated that the university education influenced the commitment in build the democratic societies, encouraging and supporting the mutual solidarity, understanding, and cooperation among all peoples, and trying to do the studies about ecological sustainability.

The lowest result generate the question about commitment in poverty reduction as a social, ethical, and environmental issue, what suggest that management students are poorer prepared to deal with poverty problems, which are the scope of interest of sociology rather than management focused traditionally on profit generation. 
Table 1. Level of commitment to the sustainability undertaken during the university education descriptive statistics $(n=300)$

\begin{tabular}{|c|c|c|}
\hline & Issues & mean SD \\
\hline & To respect for earth and life of all & 4.7031 .687 \\
\hline I2 & To build the democratic society that is participatory, sustainable, and peaceful & 4.9871 .769 \\
\hline I3 & To secure the bounty and beauty of earth for the present and future generations & 4.8371 .751 \\
\hline I4 & $\begin{array}{l}\text { To protect and restore the integrity of ecological systems of earth, with special } \\
\text { attention to the biological diversity and the natural processes that sustain life }\end{array}$ & 4.7901 .746 \\
\hline I5 & To prevent the harm as the best method of the environmental protection & $4.470 \quad 1.774$ \\
\hline I6 & $\begin{array}{l}\text { To ado } \\
\text { safegua }\end{array}$ & 4.6271 .700 \\
\hline I7 & cological s & 4.8801 .678 \\
\hline I8 & To era & $4,1401.878$ \\
\hline I9 & sustainable development & $4.690 \quad 1.752$ \\
\hline $\mathbf{I 1 0}$ & To uphold the right of all people without the discrimit & 4.8031 .938 \\
\hline I11 & ghts of the indige & 4.4631 .760 \\
\hline $\mathbf{I 1 2}$ & To apply the participatory proble & 4.5131 .705 \\
\hline I & $\begin{array}{l}\text { To encourage and support the mutual solidarity, understanding, and } \\
\text { cooperation among all peoples }\end{array}$ & 4.850 \\
\hline
\end{tabular}

Source: own research

The next step of the research was recognition of the students' intentions to apply the principles of sustainable development in the future, understood as if possible taking care of the environment and acting as a responsible and honest member of society. In 7-point scale the result of 5.643 was achieved showing the strong intention for sustainable development (Fig. 1). It indicates that present students are familiar with the issues of sustainable development and want to act as a responsible member of society in the future.

K-S d $=.20813, p<.01 ;$ Lilliefors $p<.01$

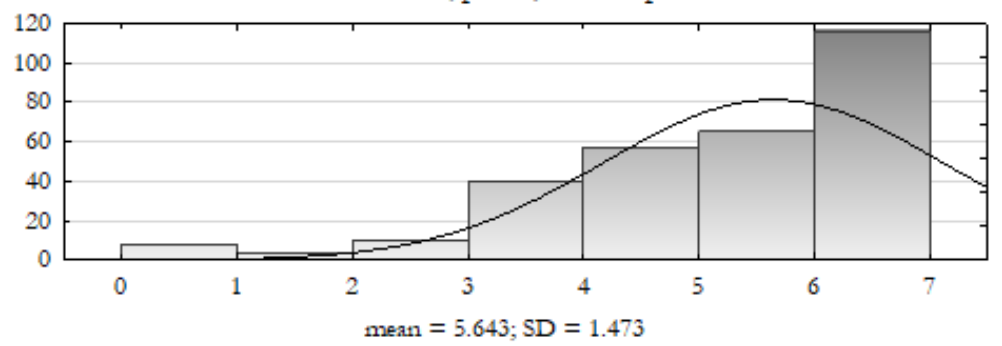

Figure 1. Intention to apply the principles of sustainable development in the future - descriptive statistics $(n=300)$

Source: own research

For the main aim realization which was the diagnosis of the current student commitment to the sustainability developed by higher education system the correlation analysis adopted. The Kendall's Tau correlation coefficient was chosen as a statistical method in which the data is not required to fit a normal distribution.

The analysis confirms the statistically significant $(\mathrm{p}<0.01)$ correlation with moderate to 
strong intensity for each analyzed pairs of questions (Tab. 2). It means that the present responsible management education which intensify commitment of students in particular areas of sustainable development would result in better applying the principles of sustainable development in the future.

Table 2: Kendall's Tau correlation analysis $(\mathrm{p}<0.01)$

Level of commitment to the sustainability

undertaken during the university education

Intention to apply the

principles of sustainable

development in the future

0.3970 .2940 .3060 .4150 .3740 .4360 .3990 .3430 .3410 .2740 .2930 .3820 .408

Source: own research

Comparing the correlations for particular sustainability issues the results differ in intensity. The strongest influence on intentions towards sustainability has the responsible education in the area of adoption the patterns of consumption, production, and reproduction that safeguard earth's regenerative capacities, human rights, and society well-being. It seems to be proper that instilling patterns translates into appropriate behaviors in the future.

The correlation value under 3.000 achieved issues connected with democratization and discrimination - the commitment in those areas generated during the study translate less to intentions to apply the principles of sustainable development in the future.

\section{Discussion and Conclusion}

Business schools face growing pressure to respond to the sustainability agenda, especially since the global financial crisis highlighted the need to educate business leaders to engage with issues beyond a profit imperative. As institutions of higher education, universities have a significant impact on society and can play a key role in sustainability provision (Dagiliūte, 2018). They can contribute most to the student's personal identity, worldview, attitudes and values. By compiling and formulating appropriate curricula and course plans, the university can shape student personality to be significantly committed in sustainability, and be an example to other institutions (Beynaghi et al., 2016).

Herzig and Moon (2013) stated, that in the light of many governance scandals, global economic crises and climate change, management education has been accused of having failed to integrate reflections on ethical values, social responsibility and sustainability into the curriculum to educate future decision-makers acting in the long term interests of business and society. As a consequence, the postulate appears to reconsider management education in order to pay a pivotal attention to issues sustainable development.

The research result analysis confirmed the need of sustainable management education clearly confirming that the increase of commitment to sustainability undertaken during the university education positively influences the intention to apply the principles of sustainable development in future life (hypothesis H1 confirmed). To shape the managers' attitude towards sustainability we need to change the education system to be more sustainability oriented, especially at the university level. As a result, students could 
obtain a high degree of involvement, increasing awareness on their role in society and need for applying the principles of sustainable development, especially taking care of the environment and acting as a responsible member of society.

The novelty of the paper was visible by exploring and developing the research problem in selected population of students from Poland. This study contributes to the international resources of knowledge within responsible management education and sustainable development area and outlines the directions of changes in educational systems to meet needs not only present but also future generations.

This paper is not free of limitations. The strongest limitation of present research is the narrow research group, so the challenge for the future could be the development of the research and comparison it with analogical groups from other countries.

\section{References}

Adomßent, M., Fischer, D., Godemann, J., Herzig, C., Otte, I., Rieckmann, M., \& Timm, J. (2014). Emerging areas in research on higher education for sustainable development - management education, sustainable consumption and perspectives from Central and Eastern Europe. Journal of Cleaner Production, 62, 1-7,

Anninos, L. N., \& Chytiris, L. S. (2012). The sustainable management vision for excellence: implications for business education. International Journal of Quality and Service Sciences, 4 (1), 61-75.

Audebrand, L. K. (2010). Sustainability in Strategic Management Education: The Quest for New Root Metaphors. Academy of Management Learning \& Education, 9 (3), 413-428.

Baumann-Pauly, C., Wickert, S. L., \& Scherer, A. G. (2013). Organizing corporate social responsibility in small and large firms: Size matters. Journal of Business Ethics, 115 (4), 693-705.

Beynaghi, A., Trencher, G., Moztarzadeh, F., Mozafari, M., Maknoon, R., \& Leal Filho, W. (2016). Future sustainability scenarios for universities: moving beyond the United Nations decade of education for sustainable development. Journal of Cleaner Production, 112, 3464-3478.

Dagiliūtè, R., Liobikienè, G., \& Minelgaitè, A. (2018). Sustainability at universities: Students' perceptions from Green and Non-Green universities. Journal of Cleaner Production, 181, 473-482.

Dobson, A. (2007). Environmental citizenship: Towards sustainable development. Sustainable Development, 15 (5), 276-285.

Faham, E., Rezvanfar, A., Mohammadi, S. H. M., \& Nohooji, M. R. (2017). Using system dynamics to develop education for sustainable development in higher education with the emphasis on the sustainability competencies of students. Technological Forecasting \& Social Change, 123, 307-326.

Fien, J. (2002). Advancing sustainability in higher education: issues and opportunities for research. Higher Education Policy. 15 (2), 143-152.

Figueiro, P. S., \& Raufflet, E. (2015). Sustainability in higher education: a systematic review with focus on management education. Journal of Cleaner Production, 106, 22-33.

Forray, J., \& Leigh, S. (2012). A primer on the principles of responsible management education: Intellectual roots and waves of change. Journal of Management Education, 36 (3), 295-309.

Godemann, J., Haertle, J., Herzig, C., \& Moon, J. (2013). United Nations principles for responsible management education: purpose, progress and prospects. Journal of Cleaner Production, 62, 16-23.

Haviernikova, K., Okręglicka, M., \& Lemańska-Majdzik, A. (2016). Cluster Cooperation and Risk Level in Small and Medium-Sized Enterprises. Polish Journal of Management Studies, 14 (2), 82-92.

Herzig, C., \& Moon, J. (2013). Discourses on corporate social ir/responsibility in the financial sector. Journal of Business Research, 66 (10), 1870-1880.

Holm, T., Sammalisto, K., Grindsted, T. S., \& Vuoris, T. (2015). Process framework for identifying sustainability aspects in university curricula and integrating education for sustainable development. Journal of Cleaner Production, 106, 164-174.

Kolb, M., Fröhlich, L., \& Schmidpeter, R. (2017). Implementing sustainability as the new normal: Responsible management education - From a private business school's perspective. International Journal of Management Education, 15, 280-292. 
Lambrechts, W., Mulà, I., Ceulemans, K., Molderez, I., \& Gaeremynck, V. (2013). The integration of competences for sustainable development in higher education: an analysis of bachelor programs in management. Journal of Cleaner Production, 48, 65-73.

Leal Filho, W. (2011). About the role of universities and their contribution to sustainable development. Higher Education Policy, 24, 427-438.

Lemańska-Majdzik, A. (2015). Selected Factors of Employees' Job Satisfaction and Business Profile of Enterprises - Results of own Research. In Central European Conference in Finance and Economics (CEFE2015), Herl'any, Slovakia, 30.09-01.10.2015, 373-381.

Matten, D., \& Moon, J. (2004). Corporate social responsibility education in Europe. Journal of Business Ethics, 54, 323-337.

Neubaum, D. O., Pagell, M., Drexler, J. A., McKee-Ryan, F. M., \& Larson, E. (2009). Business education and its relationship to student personal moral philosophies and attitudes toward profits: An empirical response to critics. Academy of Management Learning \& Education, 8, 9-24.

Okręglicka, M., Haviernikova, K., Mynarzova, M., Lemańska-Majdzik, A. (2017). Entrepreneurial Intention Creation of Students in Poland, Slovakia and Czechia. Polish Journal of Management Studies, 15 (2), 162-172.

Pace, P. (2010). Education for Sustainable Development: Current Fad or Renewed Commitment to Action? Journal of Baltic Science Education. 9 (4), 315-323.

Prandi, M., Martell, J., \& Lozano, J. (2015). Learning in a social context: PRME. Retrieved from http://www.unprme.org/resource-docs/LearninginaSocialContextReport.pdf

Rawal, D. M. (2013). Reorienting Management Education for Sustainable Prosperity. Review of Management, 3 $(1 / 2), 21-28$.

Rieckmann, M. (2012). Future-oriented higher education: which key competencies should be fostered through university teaching and learning? Futures, 44 (2), 127-135.

Rusinko, C. A., \& Sama, L. M. 2009. Greening and sustainability across the management curriculum: An extended journey. Journal of Management Education, 33(3), 271-275.

Setó-Pamies, D., \& Papaoikonomou, E. (2016). A Multi-level Perspective for the Integration of Ethics, Corporate Social Responsibility and Sustainability (ECSRS) in Management Education. Journal of Business Ethics, 136, 523-538.

Six Principles (2018). Retrieved from http://www.unprme.org/about-prme/the-six-principles.php

Steketee, D. (2009). A million decisions: Life on the (sustainable business) frontier. Journal of Management Education, 33 (3), 391-401.

Stephens, J. C., \& Graham, A. C. (2010). Toward an empirical research agenda for sustainability in higher education: exploring the transition management framework. Journal of Cleaner Production, 18 (7), 611-618.

Sterling, S., Maxey, L., \& Luna, H. (2013). The sustainable university: Progress and prospects. London: Routledge.

Verhulst, E., \& Lambrechts, W. (2015). Fostering the incorporation of sustainable development in higher education. Lessons learned from a change management perspective. Journal of Cleaner Production, 106, 189-204.

Waas, T., Verbruggen, A., \& Wright, T. (2010). University research for sustainable development: Definition and characteristics explored. Journal of Cleaner Production, 18 (7), 629-636.

Warwick, P., Wyness, L., \& Conway, H. (2017). 'Think of the future': Managing educational change from students' perspectives of an undergraduate sustainable business programme. The International Journal of Management Education, 15, 192-204.

Wiek, A., Withycombe, L., \& Redman, C. L., (2011). Competencies in sustainability: a reference framework for academic program development. Sustainability Science, 6 (2), 203-218.

Woodruff, P. H. (2006). Educating engineers to create a sustainable future. Journal of Environmental Engineering, 132 (4), 434-444.

World Convention on Environment and Development (WCED) (1987). Our common future (The Brundtland Report). Oxford: Oxford University Press.

Wu, Y.-C. J., Huang, S., Kuo, L., \& Wu, W.-H. (2010). Management Education for Sustainability: A WebBased Content Analysis. Academy of Management Learning \& Education, 9 (3), 520-531. 